\title{
Marketing of small business, A case of small business in India
}

\author{
Mr. Parthasarathi Senapati
}

\begin{abstract}
Marketing plays an important role in the success of any business organization. MSME sectors contributes towards growth the economy by creating employments and productivity. One of the typical problem faced by new start-ups are finding consumer for their goods and service. Though we know that marketing starts before the production of good $s$ and services and doesn't end with the sell of the goods. Marketing is a continuous process focused towards identifying, creating and satisfying the customers. The task of the marketing is to minimizing the distance between producers and consumer so that both can establish an exchange relationship. In India most of the Micro small medium enterprises (MSME) units are started because of the subsidy and incentives of the government. They begins to face problem relating to promotion their units when the units become operational. This paper tries to evaluate the existing marketing system and different marketing issues faced by the MSME sectors.
\end{abstract}

Keywords: MSME, Marketing system, Exchange relationship, Promotion

\section{Introduction}

Identifying the needs and wants of the of the consumers and creating goods and services to fulfill these needs is the fundamental task of the marketing function. The main objective is to establish a profitable customer relationship with target customers. Achieving these objectives require far more effort than merely making goods and service available. Every new entrepreneurs must do a great deal of deeper marketing research to understand who are his customers and how best to serve them. Research activities is a must before opening the new ventures and it must continue so long the business exists. A budding entrepreneur must make a concerted effort to establish identify the customer segments and satisfy them by delivering superior value in products and services. The focus must be on long term profitability by creating reputation for service and quality. There must be integration of other business function with the marketing effort. The market research indicates the new opportunities which requires a marketing strategy to be developed by the entrepreneurs to succeed in the market. A well formulated strategy provides guidelines to for the entrepreneurs concerning the objectives to be achieved, allocation of results, tasks to be carried out by the marketing functions and controlling the activity of the enterprise.

Indian MSMEs are in a better position than their counterpart in other Asian countries because of the growth prospects and higher level of incentives by the Govt. of India. The Micro Small and Medium Enterprises in India, constitute more than 90 per cent of the total number of industrial units and they form the backbone of industrial development. These unit are suffering because of the low scale of operation and lack of latest technology. The era of liberalization has created higher competition from the foreign imports, changing manufacturing processes, highly dynamic and changing market condition and the requirement for different strategies. There is need for MSMEs to innovate newer processes and strategies to develop products which differentiate form imported products. To face the higher level of competition from big corporates houses and MNCs, MSMEs need to be dynamic and proactive to the evolving marketing needs and innovations. The MSME sector needs to be supported with better market facilities so that they can sustain themselves and contribute to productivity, employment generation and foreign trades.

\section{Objectives of the study-}

- To evaluate the existing marketing framework for the MSME sectors

- To highlight the problem faced by the MSME sectors in marketing products and services

- To evaluate the international marketing opportunities.

- To evaluate the different strategy in a competitive and globalised environment.

\section{Literature reviews:}

*Hastings Robert, Small Business Marketing: Marketing for Small Business owners, publisher Businessman 101, edition 2011; "In this book the author has emphasized on promoting and marketing of small business by utilizing the Information technology and Web promotion"

* Hornor Jody, Reierson Vickie, Power Marketing for Small Business ,Oasis Press/PSI Research, 2000; "In this book the author has given step by step guidelines marketing of small business." 
*Robert Mark Jakobsen, Sales \& Marketing Success in Your Small Business,BoD - Books on Demand, 2011 ; "In this book the author has indicated the role of new The New World of Advertising for Small Business AdWords, Mobile Marketing, Viral Marketing, Blogs, Social Media, Videos on Web Sites."

\section{The statement of problems}

The most common issue faced by Micro, Small and Medium Enterprises (MSMEs) is lack of information on growing markets. Due to smaller size and scales of operation, they are often unable to tap markets which has the potential to absorb their products and services. They also face lack of monetary resource in competing with large corporate in Advertising and publicity. They don't have continuous fund flow to sustain their marketing effort in the market. However the protection given by the government towards small and medium enterprises helping in avoiding competition from big corporate.

Fast changing global economic environment has provided various opportunities and challenges to the MSMEs in India. While on the one hand, it has opened up newer opportunities for growth and business expansion and at the same time it has created newer threats to the business. The sector has to increase productivity and explore for new markets both at national and international level. The small business has to improve the technology and they don't have any strategic alternatives for their business/ market development as it is being available with large industries. In the present competitive age, Marketing is one of the vulnerable part of the MSMEs sectors.

Out of several problems faced by small and medium scale enterprises, the absence of adequate marketing and export facilities is one of the major concerns. Almost all types of business enterprises face marketing problems, but the small and medium scale enterprises face greater difficulty in the marketing and distribution of their products. Some of these are:-

- Small and medium entrepreneurs tend to face tough competition from the products and sales/ marketing strategies of large scale enterprises. They face the difficulty in terms of cost, quality, standards, popularity, meeting ever-changing demands/ preferences of consumers, etc.

- They lack their own marketing distribution network. So, they depend on external agencies for distributing their outputs. This ultimately increases the cost of their products and services.

- Most of the small entrepreneurs are unaware of the modern marketing and business strategies. As a result, they are unable to cope quickly with changing market scenarios. Though the products they produce has huge market potential but they unable to opt for efficient marketing techniques.

- They lack effective sales promotion because of the lack of funding and resources. They cannot afford to spend much on advertising, sales promotion, market research, etc.

- They find it difficult to sell their output at a profit because of higher cost of production and nonstandardized quality of products.

- They also have to sell their products at a loss because they cannot bargain with the big buyers and requirement for the urgent need of working capital.

- Small business often find it difficult to tap foreign markets for their products, either due to lack of awareness on the potential markets or due to inadequate information on various regulations, guidelines and procedures for exporting to the foreign markets.

Thus, it is right to say that most of small and medium entrepreneurs do not correctly understand as to what kind of products are actually needed by the market, how big/small is the market, when the products are needed and how to deliver such products. All these problems keep them mainly isolated from the market trends and conditions and, thus, tend to restrict their operations.

\section{Existing marketing framework for small business sectors in India}

Marketing as a tool for success has not yet developed in the small business sector. Professional marketing companies and consultant are not engaged by small entrepreneurs on account of lack of finance. The concept of marketing is not known to the majority of small entrepreneurs in India For majority of the small entrepreneurs, marketing means advertisement or personal contacts. These attitudes towards marketing needs to be changed. Most of the small business markets their product by themselves by establishing a sales department to identify consumers both domestic as well as international. They establish close contacts with a known selected group of customers by finalizing technical and commercial terms to manufacture and supply. The direct consumer contact is generally long term in nature and helps the company to build strong relationship with them. In many cases the profit realization in this process is more than other mode of marketing. Some of the common practice among the Small business in India to market their product and services are as follows,

i. Indenting Agents: MSMEs find an indenting agent who can guarantee a specified business on mutually agreed terms. Indenting agent books orders on behalf of the company and material will be dispatched to the consumer directly by the producer .Based on the projections of indenting agent, SME manufactures the product. In this mode the MSMEs, gets assured business, without spending on marketing resources. 
ii. Traders: MSMEs will identify traders who can guarantee a specified business on mutually agreed terms. Based on projections of traders MSME will manufacture and supply to the traders. The traders stock the material in their warehouse and markets in his jurisdiction. In this mode the MSMEs without spending on marketing resources, gets assured business, but mostly it is of credit sales and fund realization takes long time and the profit margins are low to other modes.

iii. Third Party manufacturing: In third party manufacturing, the MSME manufactures the product as per the specifications of third party and supplies the finished products to them. The MSME will charge the third party on mutually agreed terms; normally it includes production cost and a small profit margin.

iv. Propaganda-Cum-Distribution: The small entrepreneurs appoint region wise propaganda cum distributing agents. The unit manufactures the product as per the agreed formulation. It is the responsibility of the propaganda cum distributor to promote the product and generate the sale in his jurisdiction. In this mode MSME gets assured sale but margins are low.

v. Contract manufacturing: In Contract manufacturing, MSMEs gets all raw materials and packaging materials from contracting organization. Material is manufactured using facilities and manpower of MSME. MSME will be paid for the production cost which will be decided on mutual agreed terms. Any liability in manufacturing is the responsibility of the contractor.

vi. Institutional Sales/tender marketing: Institutional marketing comprises of,

- To State and Central Govt. agencies and Govt. promoted trade exhibitions.

- To Govt. agencies such as Railways, Defense ,telecom, etc

- Large industrial houses or PSUs in India.

- To big corporate groups in Private Sectors in India.

To participate in State and Central Govt. tenders, the MSME should have made the products for a minimum of three years. Entrepreneurs with long standing manufacturing activities would opt for institutional marketing.

Majority of organizations follow combination of all above marketing mode to sale their product. New entrants prefer to tie up with large organization as contract manufacturers.

\section{Marketing assistance programme by Government:}

Marketing, a strategic tool for business development, is critical for the growth and survival of micro, small \& medium enterprises. Marketing is the most important factor for the success of any enterprise. Large enterprises have enough resources at their command to hire manpower to take care of marketing of their products and services. MSME sector does not have these resources at their command and thus needs institutional support for providing these inputs in the area of marketing.

Ministry of MSME has also been providing marketing support to Micro \& Small Enterprises (MSEs) under Marketing Assistance Scheme through National Small Industries Corporation (NSIC).There are Governmental and non-governmental specialized agencies which provide marketing assistance. NSIC \& KVIC are the devoted govt. agencies for providing marketing assistance to MSME units. The supports schemes are as follows,
a) Organizing International Technology Exhibitions in Foreign Countries by NSIC and participation in International Exhibitions/Trade Fairs:
b) Organizing Domestic Exhibitions and Participation in Exhibitions/ Trade Fairs in India:

c) "Techmart" exhibition by NSIC:

\section{d)Support for Co-sponsoring of Exhibitions organized by other organizations/ industry associations/agencies: \\ e)Buyer-Seller Meets organized by NSIC. \\ f)Intensive Campaigns and Marketing Promotion Events:}

\section{Conclusion and findings}

The analysis of the various problems and marketing activities of the Small business in India indicates that there is no single perfect plan for promotion Since MSME play a pivotal role in the economic and social development of the country, often acting as a foundation for growth entrepreneurship. The neglect of marketing will make the sector completely handicapped..MSMEs have been globally considered as an engine of economic growth and as key instruments for promoting equitable development. The marketing consultants as well as the Govt. must make effort to designing a viable plan for the development of the MSME sectors. The major advantage of the sector is its employment potential at low capital cost. The various alternative plan needs to be analyzed to fin the a solution for the MSME sectors.In recent years, the MSME sector has consistently registered higher growth rate compared with the overall industrial sector. With its agility and dynamism, the 
sector has shown admirable innovativeness and adaptability to survive .Developing innovative marketing strategy is the need of the hour for growth and sustainability of MSME sectors.

\section{References}

[1]. Vidya Suresh and P shashidhar, Competitiveness of Small-Scale Industries of India, Conference on Global Competition \& Competitiveness of Indian Corporate.

[2]. Nyati, K. (1988). Problems of pollution and its control in small-scale industries.

[3]. Gupta, M. \& Sharma, K. (1996, third quarter). Environmental operations management: An opportunity for improvement. Production and Inventory Management Journal, 40-46.

[4]. Manimala J. Mathew, (2006), Entrepreneurship Education and Training in India: Global Education, University of Essex, Scotland.

[5]. Ahluwalia, I.J., (1985) Industrial Growth in India: Stagnation Since the Mid- Sixties(London, Oxford University Press).

[6]. Lal, K Anil and Clement W. Roland, (2005), Economic Development in India; The role of Individual Enterprises, Asia-pacific Development Journal, Vol 12. No 2.

[7]. Acs J. Zoltan,(2007), How is Entrepreneurship good for Economic Growth?, Progress Foundation, Zurich: Switzerland.

[8]. (MSME) Annual Report 2010-11.

[9]. http://smallb.in/\%20/manage-your-business\%20/marketing

[10]. http://msmehyd.ap.nic.in/Documents/Top Panel/NMCP Schemes/MATU.doc

[11]. http://business.gov.in/enterprises/marketing.php

[12]. http://www.du.ac.in/fileadmin/DU/Academics/course_material/EP_16.pdf

[13]. http://www.legalpundits.com/Content folder/SMEArti150610.pdf 